\title{
The Solution To The Damage Of Kariba Dam
}

\section{Changfeng $\mathrm{Li}$}

\section{School of NORTH CHINA ELECTRIC POWER UNIVERSITY(Baoding), BaoDing 071000, China}

az751428870@126.com

\section{Abstract:}

The Kariba dam spans the border between Zimbabwe and Zambia and has two power stations in the north and south, providing more than 50 percent of electricity to Zambia and Zimbabwe and benefiting about 4.5 million people. But now the Kariba Dam was damaged seriously. Once it collapses, it will directly threaten the lives of more than 3.5 million inhabitants of Zambia, Zimbabwe, Mozambique and Malawi, as well as the supply of electricity throughout the region.

At the present stage, there are three solutions to this matter, such as repairing the Kariba Dam, rebuilding the Kariba Dam and dismantling the Kariba Dam to rebuild multi-dam system. In this paper, the three schemes are analyzed by using AHP. We find that the solution of dismantling the Kariba Dam to rebuild multi-dam system is the best solution. In order to make the dam to meet the overall level of the original dam, a large-scale multi-objective decomposition and aggregation model of power generation, flood control, drought resistance and irrigation is established, which is based on the energy conservation and energy conversion law, giving a constructive reference to the level of power generation of small dams. What's more, the multi - dimensional and multi - objective discrete - time differential dynamic programming drought - resistant scheduling model and multidimensional multi - objective discrete - time differential dynamic programming flood control model are introduced to provide the concrete guidance and use for the maximum discharge and minimum emission of dams.

We not only establish mathematical model to solve the emergency water flow problems successfully but also use the arch crown beam method for dam stress analysis, in order to ensure the safety of the dam. Finally, a cost-benefit model is introduced to analyze the cost and benefit of dam construction. Combined with the hydrological characteristics, human environment and the requirements of dam construction, the optimal construction scheme is determined.

\section{Keywords: Kariba Dam; AHP;}

\section{Introduction}

\subsection{Assessment Report}

Since the solution to the Kariba dam problem is complex and varied, the three options are briefly evaluated by using the AHP method, both from potential costs and benefits. Among them, because of 
the many factors of the potential cost, we broadly divided the cost into construction costs and management costs.

\subsubsection{Establish the index system}

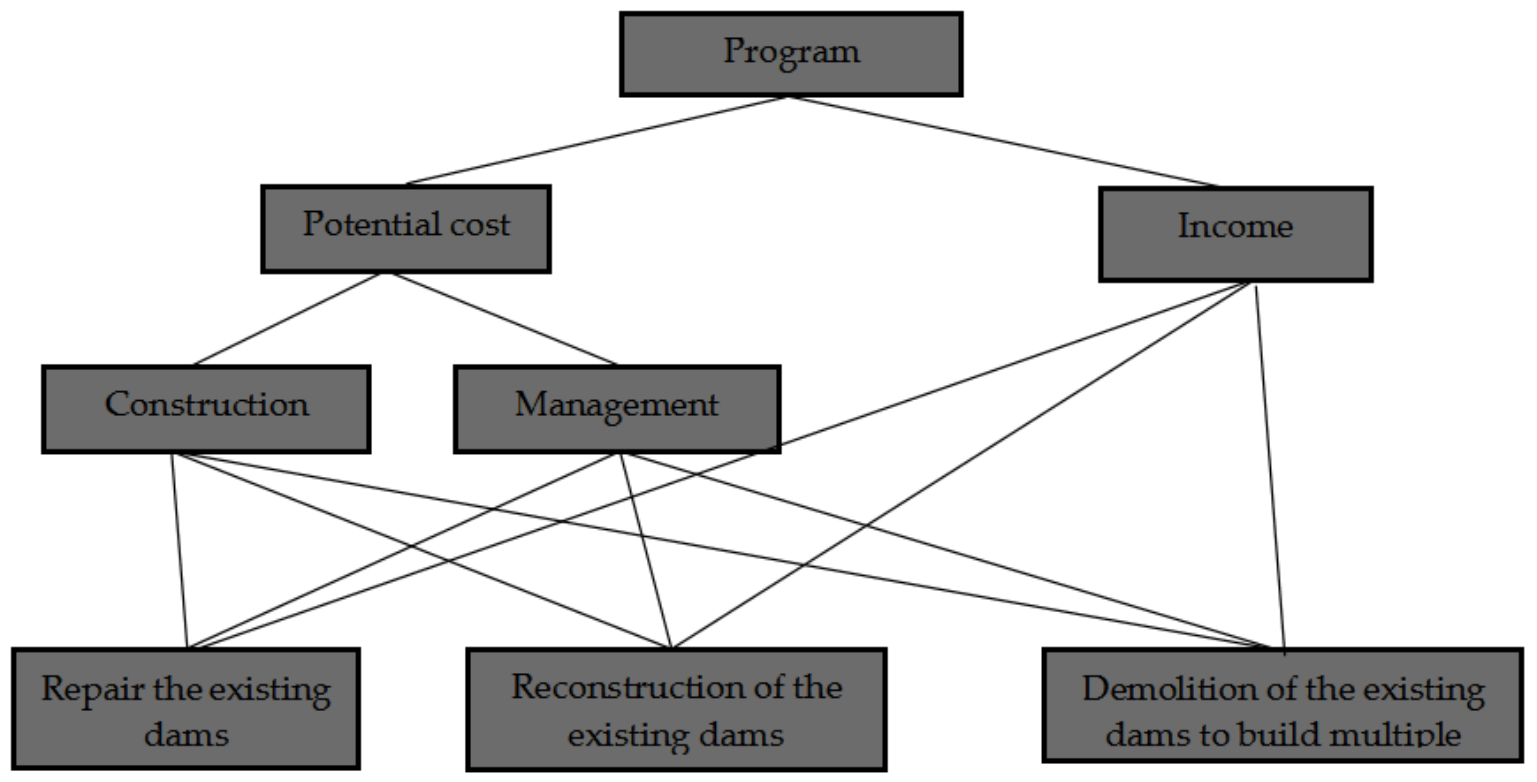

Fig 1 The establishment of the index system

\subsubsection{Evaluation of the weight of the evaluation system by AHP}

The selection criteria of the importance of the program, see Table 1.

Table 11 to 9 Number Scale

\begin{tabular}{|c|c|c|c|c|c|c|c|}
\hline Scale $\mathbf{a}_{\mathrm{ij}}$ & $\begin{array}{ll}12 \\
\end{array}$ & 3 & 4 & 5 & 6 & 8 & 9 \\
\hline Relative & The same & Slightly & & Stronger & & Significantly & Absolutel \\
\hline Importance (Ci: $\mathbf{C j})$ & & stronger & & & & stronger & y strong \\
\hline
\end{tabular}

aij $=1,1 / 2, \ldots 1 / 9 \sim \mathrm{Ci}: \mathrm{Cj}$ The relative importance is the reciprocal of the above

Based on the above solution, the weights of the alternatives in the selection of targets are shown in Table 2.

Table 2 Hierarchical Total Sorting

\begin{tabular}{lc}
\hline Options & W \\
\hline Repair the existing dams & 0.1731 \\
Reconstruction of the existing dams & 0.3478 \\
Demolition of the existing dams to build & 0.4791 \\
multiple small dams & \\
\hline
\end{tabular}

From the above we can see that the weight of the repairing the existing dam is the smallest, accounting for $17.31 \%$ of the target weight. The weight of demolition of the dams to build multiple 
small dams is the largest, accounting for $47.91 \%$ of the target weight and the third option is selected to maximize the comprehensive benefit between the potential cost and the benefit.

\section{Problem Analysis}

\subsection{Analysis one}

By analyzing the potential costs and benefits, we can briefly assess the three options including repair of the existing dams, reconstruction of the existing dams and removal of the existing dams to rebuild a series of small dams. In order to be able to view all aspects of the problem, we decided to use Analytic Hierarchy Process (AHP).

\subsection{Analysis two}

The Kariba Dam was dismantled and converted into a series of ten to twenty smaller dams along the Zambezi River. The new dam system will have the same or higher level of protection and water management capabilities as existing Kariba dams. By balancing the water flow in the new multi-dam system, safety and cost are balanced.

\section{The Establishment and Solution of Model}

\subsection{Using AHP to Solve the Weight of Evaluation Index System}

The consistent matrix of the relative weights constructed by the two pairs of indicators in each layer of the indicator system is shown in Table 3, Table 4, Table 5, Table 6 and Table 7.

Table 3 Judgment Consistency Matrix for Program Evaluation and Its Results

\begin{tabular}{cccc}
\hline Case evaluation & Potential cost & income & Wi \\
\hline Potential cost & 1.0000 & 0.2500 & 0.2000 \\
income & 4.0000 & 1.0000 & 0.8000 \\
\hline
\end{tabular}

Table 4 Determine the consistent cost matrix and its results

\begin{tabular}{cccc}
\hline Potential cost & Construction cost & Management costs & Wi \\
\hline Construction cost & 1.0000 & 2.0000 & 0.6667 \\
Management costs & 0.5000 & 1.0000 & 0.3333 \\
\hline
\end{tabular}

Table 5 Judgment of income Consistency matrix and its results

\begin{tabular}{ccccc}
\hline income & $\begin{array}{c}\text { Repair existing } \\
\text { dams }\end{array}$ & $\begin{array}{c}\text { Reconstruction } \\
\text { of existing } \\
\text { dams }\end{array}$ & $\begin{array}{c}\text { Remove the } \\
\text { dam to build } \\
\text { multiple dams }\end{array}$ & Wi \\
\hline $\begin{array}{c}\text { Repair } \\
\text { existing dams }\end{array}$ & 1.0000 & 0.2000 & 0.2500 & 0.0989 \\
$\begin{array}{c}\text { Reconstructio } \\
\text { n of existing } \\
\text { dams }\end{array}$ & 5.0000 & 1.0000 & 0.5000 & 0.3643 \\
$\begin{array}{c}\text { Remove the } \\
\text { dam to build } \\
\text { multiple dams }\end{array}$ & 4.0000 & 2.0000 & 1.0000 & 0.5368 \\
\hline
\end{tabular}


Table 6 Judgment Coherence Matrix for Construction Costs and Their Results

\begin{tabular}{ccccc}
\hline $\begin{array}{c}\text { Construction } \\
\text { cost }\end{array}$ & $\begin{array}{c}\text { Reconstruction } \\
\text { of existing } \\
\text { dams }\end{array}$ & $\begin{array}{c}\text { Remove the } \\
\text { dam to build } \\
\text { multiple dams }\end{array}$ & $\begin{array}{c}\text { Repair existing } \\
\text { dams }\end{array}$ & Wi \\
\hline $\begin{array}{c}\text { Reconstructio } \\
\text { n of existing } \\
\text { dams }\end{array}$ & 1.0000 & 3.0000 & 5.0000 & 0.6566 \\
$\begin{array}{c}\text { Remove the } \\
\text { dam to build } \\
\text { multiple dams }\end{array}$ & 0.3333 & 1.0000 & 1.0000 & 0.1852 \\
$\begin{array}{c}\text { Repair } \\
\text { existing dams }\end{array}$ & 0.2000 & 1.0000 & 1.0000 & 0.1562 \\
\hline
\end{tabular}

Table 7 Judgment Consistency Matrix for Management Costs and Their Results

\begin{tabular}{ccccc}
\hline $\begin{array}{c}\text { Management } \\
\text { costs }\end{array}$ & $\begin{array}{c}\text { Repair existing } \\
\text { dams }\end{array}$ & $\begin{array}{c}\text { Remove the } \\
\text { dam to build } \\
\text { multiple dams }\end{array}$ & $\begin{array}{c}\text { Repair existing } \\
\text { dams }\end{array}$ & Wi \\
\hline $\begin{array}{c}\text { Repair } \\
\text { existing dams }\end{array}$ & 1.0000 & 3.0000 & 5.0000 & 0.6267 \\
$\begin{array}{c}\text { Remove the } \\
\text { dam to build } \\
\text { multiple dams }\end{array}$ & 0.3333 & 1.0000 & 4.0000 & 0.2797 \\
$\begin{array}{c}\text { Repair } \\
\text { existing dams }\end{array}$ & 0.2000 & 0.2500 & 1.0000 & 0.0936 \\
\hline
\end{tabular}

\subsection{Power Generation}

The Kariba dam provides more than $50 \%$ of the electricity used in Zambia and Zimbabwe, so the newly built dams must be able to satisfy the original dam power supply function. The model is analyzed to ensure that the total dams power generation capacity is not less than the existing dam's overall power generation capacity.

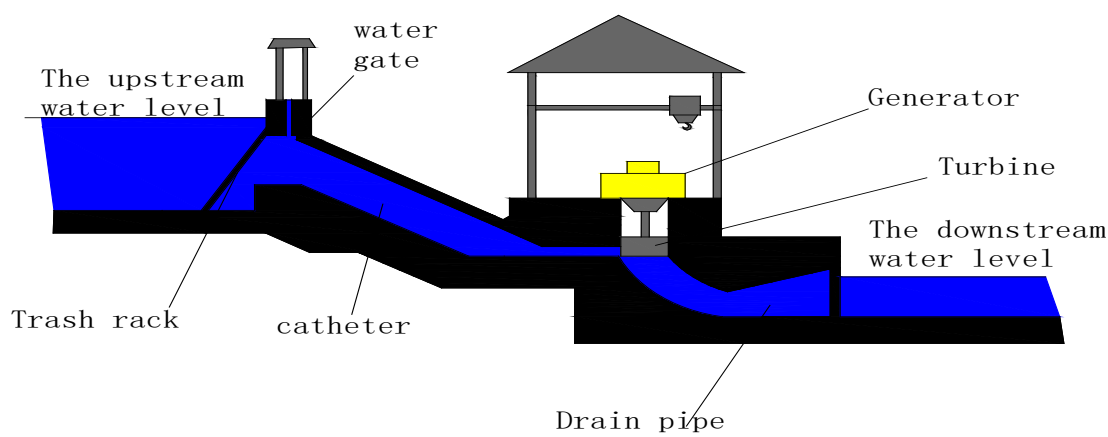

Fig 2 Schematic diagram of dam power generation

According to the energy conservation theorem, we can get the following equations: 


$$
\begin{aligned}
& 1 / 2 m v_{0}^{2}+m g h=1 / 2 m v^{2}, \\
& h=1 / 2 g t^{2}, \\
& m=\rho V_{0}, \\
& V_{0}=Q t,
\end{aligned}
$$

Then we can get the equations as follows:

$$
\begin{aligned}
& \rho Q \sqrt{2 g h} h+1 / 2 \rho Q \sqrt{2 g h} v_{0}^{2}=1 / 2 \rho Q \sqrt{2 g h} v^{2}, \\
& E=1 / 2 \rho Q \sqrt{2 g h v^{2}}, \\
& E_{i}=\eta E,
\end{aligned}
$$

In order to make the new dam reach the level of the original dam power generation, the following inequality should be satisfied:

$$
\sum_{i=1}^{n} E_{i} \geq E_{A}
$$

\section{Conclusions}

\subsection{Advantages}

We utilizes the principle of conservation of energy, using a variety of models and analytical methods to provide a theoretical support to solve the problem

The solution is more comprehensive, involving various subject knowledge Extensive models are built

\subsection{Limitations}

Due to time and capacity constraints, we were unable to gather large amounts of actual data to support our model.

We considered a number of factors, but because each aspect was more complex, only the main factors were selected.

\section{References}

[1]http://www.mofcom.gov.cn/article/i/jyjl/k/201501/20150100864271.shtml

[2] Tauxe G W. Multi-objective Dynamic Programming with Application to a Reservoir [J]. Water Resources Research, 1979, 15 (6): 1403-1408.

[3] Fuquan Ni, Yu Deng, Jian Hu and so on. Practical Teaching Guidance of Hydraulic Engineering. 